\title{
Implementation of Economic Empowerment Model Based on Export Opportunities Towards the ASEAN Economic Community (A Case Study of Wonogiri Regency)
}

\author{
Nurul Istiqomah $^{1 *}$, Supriyono ${ }^{2}$ and Izza Mafruhah ${ }^{3}$ \\ 1,2,3 Fakultas Ekonomi dan Bisnis, Universitas Sebelas Maret Surakarta, Indonesia
}

\begin{abstract}
Objective - This research carries three objectives. First, it aims to analyse the variables that affect readiness in facing the AEC. Second, it aims to analyse aspects that can affect the preparation of the empowerment model based on the economic potentials of the Wonogiri community for export opportunities. Finally, it aims to see how the proposed model can be implemented as an empowerment model.

Methodology/Technique - The analytical tools used in this research include a descriptive statistical analysis and the Analytical Hierarchy Process (AHP) is used to determine aspects affecting the preparation of the empowerment model. In the Qualitative analysis of the implementation of the empowerment model, data will be drawn from focus group discussions and in-depth interviews.

Findings - Results show that factors affecting the success of empowerment on communities include education age, capital, business types, and entrepreneurial experiences. Priority variables noted in the preparation of the empowerment model include three aspects: internal aspects of business players and community, institutional aspects, and external aspects. Results also indicate that the model is applicable for the empowerment efforts of business players and community in the Wonogiri regency in facing the AEC.

Novelty - Community empowerment model for the AEC has not been specifically conducted in Wonogiri. Thus, in drawing up a strategic plan for the years 2016-2020 as contained in RPJMD Wonogiri, the government has only planned for the empowerment programs in general.
\end{abstract}

Type of Paper: Empirical

Keywords: Economic Empowerment Model; Analytical Hierarchy Process; Wonogiri Regency; Indonesia.

JEL Classification: F63, P25.

\section{Introduction}

The ASEAN Economic Community (AEC) is a form of collaboration opportunities between ASEAN member countries whose aim is to improve access among these countries so as to enhance mutual prosperity. With the increasingly thin boundaries existing between countries due to globalization, the

\footnotetext{
* Paper Info: Received: October 2, 2016

Accepted: December 23, 2016

* Corresponding author:

E-mail: nurulistiqomah1980@yahoo.com

Affiliation: Fakultas Ekonomi dan Bisnis, Universitas Sebelas Maret Surakarta, Indonesia
} 
capability of countries in creating quality products at a competitive price that is acceptable by the market is necessary. However, creating products at competitive prices can be viewed from two perspectives: opportunity and challenge. From the opportunity perspective, creating products can mean developing new products so as to meet domestic needs, thereby, cutting down the purchase of foreign products. Alternatively, creating products can mean developing new products for the purpose of exporting, thereby, increasing foreign exchange. In terms of challenge, countries thinking of creating new products will need to think about developing their own human resources so as to be able to compete with foreign competence.

The ASEAN free market is still highly dependent on the readiness of its member countries' ability to exploit its own strengths and then map these strengths strategically so as to be able to enter the free market competitively. Through this, the ASEAN free market will then be able to provide opportunities for an increased welfare of all the member countries. Wonogiri is one area in the Central Java province of Indoneisa which needs to be able to capture these opportunities. Wonogiri has a low GDP compared to other regions and its low GDP is caused by several factors, one of which is the lack of productive and skillful human resources. This is because many of Wonogiri's human resources have migrated to other more developed areas around Wonogiri as a means of achieving better living standards. Consequently, many of those who had remained behind in Wonogiri are those who are generally low in education and ability and high in age. This is despite the natural wealth that is located in the region. their region. As a result, the level of welfare in Wonogiri has remained stagnant.

The results of a study conducted in 2015 investigating the readiness of the Wonogiri regency in meeting a competitive free market indicated that both the opportunities and challenges need to be addressed through supportive policies and programs. However, thus far, the government has not given any priority or relevant attention to Wonogiri through explicit policies. Moreover, the current program and budget that support the AEC at the central and local government levels have not been followed up by a clear commitment. Linked to this lack is the fact that many of the business activities undertaken by business enterprises have not been duly directed towards meeting the objectives of the AEC. In this regard, it would appear that goods are still product oriented rather than market oriented. Observation shows that the main priority of businesses in the area of Wonogiri seems to be focused on how to keep the production line running and surviving rather than how to produce quality products. In that regard, innovation and market expansion, have not become the regency's priority and this is because the impact of the AEC has not been felt by the local community. In contrast, the influx of goods from other ASEAN countries has led to an increase in product choices for the locals as well as more competitive prices of products. For the local community to be more competitive, it cannot be denied that getting involved with socialization and developing campaigns such as "Cinta Produk Dalam Negeri" (Love for Domestic Products) would be able to raise higher awareness among the locals.

Indonesia's success in facing the AEC is not only determined by the central and local governments but also by its businesses, especially Small and Medium Enterprises (SME). Thus, in order for the AEC to be effective in Indonesia, the local communities need to be optimally empowered. This empowerment should be based on three aspects: (1) the internal aspects of business players and communities encompassing education, business experience, and capital; (2) the external aspects of education, training, and mentoring, capital aid and market access; (3) the institutional aspects of business legality, government regulations, programs and budget. These three aspects are prioritized differently in each business community depending on local conditions, potential, and main business sectors.

Empowerment has been the keyword in the concept of readiness to face the AEC. Sulistiyani (2004) explains this in more detail by saying that, etymologically, empowerment was derived from the word "power" which means strength or capability. Based on this meaning, empowerment is thus defined as a process of obtaining power, strength, or capability, or the process of giving power, strength, or capability from parties with the power to those lacking in power. Empowerment requires the enrollment of businesses and community and in this regard, enrollment implies that main actors need to always be included in the planning, implementation, production, enjoyment, and preservation. Sustainable empowerment needs to meet the 
following criteria: (1) Involving all members of community (community) in every development stage; (2) Involving any member of the community with the sacrifice which means that those who produced can also enjoy and benefit in accordance with its ability to produce, (3) Involving the use of tolerance among communities in which they work in accordance with its competence.

A research by SMERU entitled "The capacity of poverty reduction institutions in the regions" in 2007 showed the role of the government in initiating the institutional aspects in community empowerment in several areas including Jembrana, Balikpapan, Gorontalo and Sragen Regency. These four regions have different features and characteristics and their differences were caused by various aspects such as geographical, demographic, and socio-cultural conditions. Similarly, the Wonogiri regency will also need a different model of empowerment, specifically, so as to be ready to face the AEC.

\section{Literature Review}

The AEC is the ASEAN free trade zone that requires each member state to have special advantages and the ability to compete with other countries. Adam Smith (1776) stated that absolute advantage is the ability of a country to produce goods or services per unit using fewer resources as compared to those of other countries. However, Ricardo (1817) stated that the basic specialization in international trade does not have to be absolute advantage, but instead, a comparative advantage. Comparative advantage is the advantage not obtained because of decision or because other alternative has been taken. Comparative advantage occurs when there are differences in opportunity cost among the countries participating in international trade (Deliarnov, 1995).

Free trade has two effects. Positive effect occurs when communities concerned have more choices of products with competitive quality and prices, and countries that are able to create such products will get an increased demand for such products, thereby, creating a higher foreign exchange. On the other hand, negative effect occurs when such free trade includes consumerism and human resource competition between countries. This competition between countries may lead to new unemployment in countries with low quality human resources because of their inability to compete. Thus, in order for the respective governments to mitigate the effect of these two effects, the respective governments need to undertake important steps which should involve the local community and SMEs through empowerment. The concept of empowerment emerges due to dissatisfaction with the theoretical model of development and industrialization that has been less supportive of the local community. Community economic empowerment is the strengthening of production factor ownership, strengthening of distribution and marketing control, and strengthening of the communities to obtain information, knowledge, and skills, which need to be done through a multi-aspect approach, both by the local community itself and through policy. There are two factors that affect community empowerment, i.e. internal factors and external factors (Subejo \& Iwamoto, 2003) as shown in Figure 1 below: 


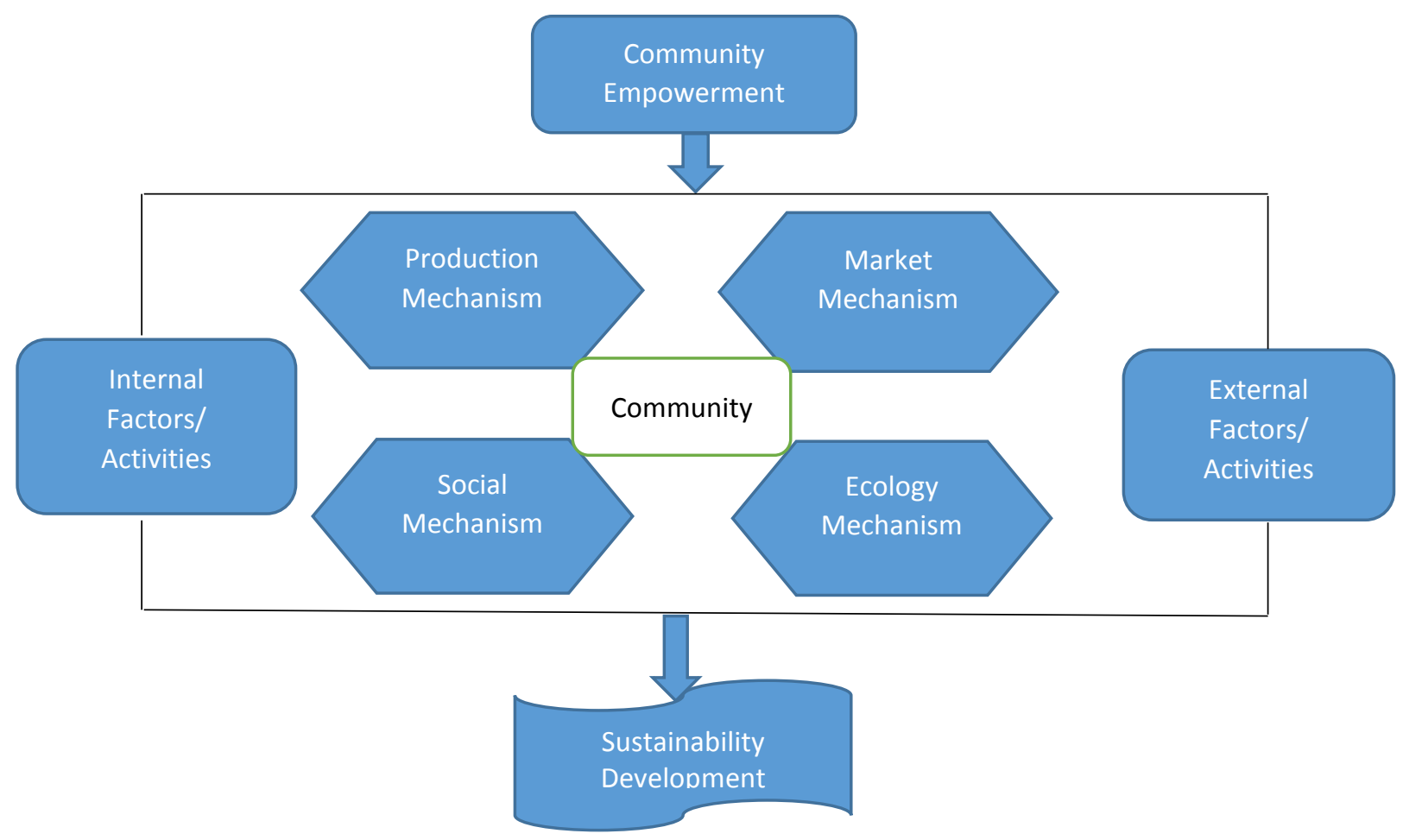

Figure 1. Community Empowerment towards Sustainable Development

In another research, "Pemberdayaan Masyarakat Miskin Berbasis Kearifan Lokal" (Empowerment of the Poor Based on Local Wisdom), Saharudin (2009) was able to conclude that the development of an empowerment model that takes into account local wisdom is necessary so as to reduce poverty. Local wisdom is the result of the interaction occurring between community and its environment and local wisdom helps the community to become self-sufficient.

\section{Research Methodology}

The analytical tools used in this study are of three parts:

Part 1: Descriptive statistics to analyze the variables that affect the successful implementation of business empowerment in facing the AEC. The respondents in the first analysis comprise of business players and community members.

Part 2: Analytical Hierarchy Process (AHP) which is used to break down a complex problem into hierarchical groups. Respondents in the second part of the analysis were also made up of business players and the local government. In this study, three main variables were examined and they include:

a) institutional aspects consisting of:
i. the legality of the business,
ii. government regulations,
iii. geographic potential,
iv. government program and budget;

b) internal aspects consisting of:
i. education,
ii. business experience, 
iii. capital owned; and

c) external aspects consisting of:

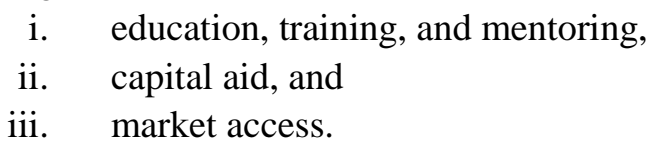

The third analysis tool is the focus group discussions and in-depth interview.

\section{Discussion}

The Wonogiri regency possesses many valuable resources with key potentials seen in its agriculture, fisheries and plantations, as well as other natural resources. However, in reality, Wonogiri exports only a few products. Data obtained from the Department of Commerce showed that the exported commodities include traditional herbs, essential oils, grass jelly, cassava, mosaic stones, and tilapia fillet with the largest export value contributed by the tilapia fillet. Data also indicate that the goods exported were raw materials that do not possess a high added value when in fact, the biggest advantage could have been obtained from its processing industry. This potential of Wonogiri needs to be optimally developed.

The field survey of 30 respondents provided data which were analysed using descriptive statistical analysis. Results showed that the variables that affected the readiness of Wonogiri in facing the AEC include:

1. Business access, which is the ability of the community and business players to obtain the ease of conducting business. The results of the study indicate that not all business players have a better access to business and this is because of:

(a) the absence of documentation and financial statements of the business;

(b) the absence of guarantees or collateral that meet the requirements of the credit/loan;

(c) the absence of business legality;

(d) the absence of clear information about access and networking for business improvement.

2. Market Access, transition from subsistence to commercial enterprises is often referenced to as the commercialization of business fields. Market aspect, in addition to output market, also plays a role as a guarantee of the input availability as raw materials become particularly important variables in guaranteeing business continuity. The availability and affordability of input/raw material market will significantly affect transportation costs that will then subsequently, increase the overall production costs. The results show that in the Wonogiri regency, input market and domestic output market aspects are relatively satisfactory.

3. Business access of legality and licensing from the PIRT and BPOM (Food and Drugs Supervisory Board) is important for the standardization of products. Currently, business legality has become an integral part of production because it is meant to maintain the legal security and comfort in business operations. The results of the field study show that only $40 \%$ of businesses possess business legality.

4. Technological access, which is used in the production process, particularly the production techniques used by business players, showed that small businesses, typically uses appropriate or intermediate technology that is relatively inexpensive and non-factory production. Thus, even if the technology is damaged, it can be easily be repaired or serviced by a local workshop. Information about the novelty of this technology can be obtained through education or training undertaken by the local government and attended by business players. 
The aforementioned four accesses should be equally affordable for businesses, so they would be able to maximize their production.

AS stated earlier, the second objective of this research is to analyze aspects that affect the preparation of the empowerment model based on community economic potential in Wonogiri on export opportunities. Table 1 shows the results of the AHP calculation.

Table 1. Results of AHP analysis on the major factors

\begin{tabular}{lrr}
\hline Criteria & Priority Values & Rank \\
\hline Institutional & 0.34585 & 2 \\
Internal & 0.37970 & 1 \\
External & 0.27445 & 3 \\
\hline
\end{tabular}

Sources: Primary data

Of the aspects examined, results show that the aspect considered to be the most influential on community empowerment as perceived by the business players and government is Internal aspects with a priority value of 0.3797 . This is followed by Institutional aspects with a priority value of 0.3458 . The final ranking is External aspects with a priority value of 0.2744 . In addition, it was noted that Internal aspect consists of three derivative factors: education, business experience, and capital owned. Results of the analysis are shown in Table 2.

Table 2. Results of AHP Analysis on the Internal Aspects

\begin{tabular}{|c|c|c|}
\hline Criteria & $\begin{array}{l}\text { Priority } \\
\text { Values }\end{array}$ & Rank \\
\hline Education & 0.41003 & 1 \\
\hline Business experience & 0.29234 & 3 \\
\hline Capital owned & 0.29763 & 2 \\
\hline
\end{tabular}

Sources: Primary data

While Internal aspects consist of four derivatives, Institutional aspects consist of four variables encompassing: business legality, government regulations, program/budget, and geographic potential. The results of the analysis are shown in Table 3.

Table 3. Results of AHP Analysis on the Institutional Aspects

\begin{tabular}{|c|c|c|c|}
\hline Criteria & $\begin{array}{l}\text { Priority } \\
\text { Values }\end{array}$ & Rank & \\
\hline Legality & 0.30052 & & 1 \\
\hline Government regulation & 0.26041 & & 2 \\
\hline Program / Budget & 0.22682 & & 3 \\
\hline Geographical & 0.21225 & & 4 \\
\hline
\end{tabular}

Sources: Primary data

The last, External aspects consist of three factors including training and mentoring, capital, and market. In this regard, Market serves as the key priority followed by training and mentoring, and then capital from external parties. The results of the analysis are shown in Table 4.

Table 4. Results of AHP analysis on the External Aspects

\begin{tabular}{lrr}
\hline Criteria & $\begin{array}{l}\text { Priority } \\
\text { Values }\end{array}$ & Ranked \\
\hline Training, mentoring & .3379 & 2
\end{tabular}




\begin{tabular}{lll} 
Capital & .2849 & 3 \\
Market & .3772 & 1 \\
\hline
\end{tabular}

Sources: Primary data

These aspects will be further organized in the empowerment model as shown in Figure 2 below.

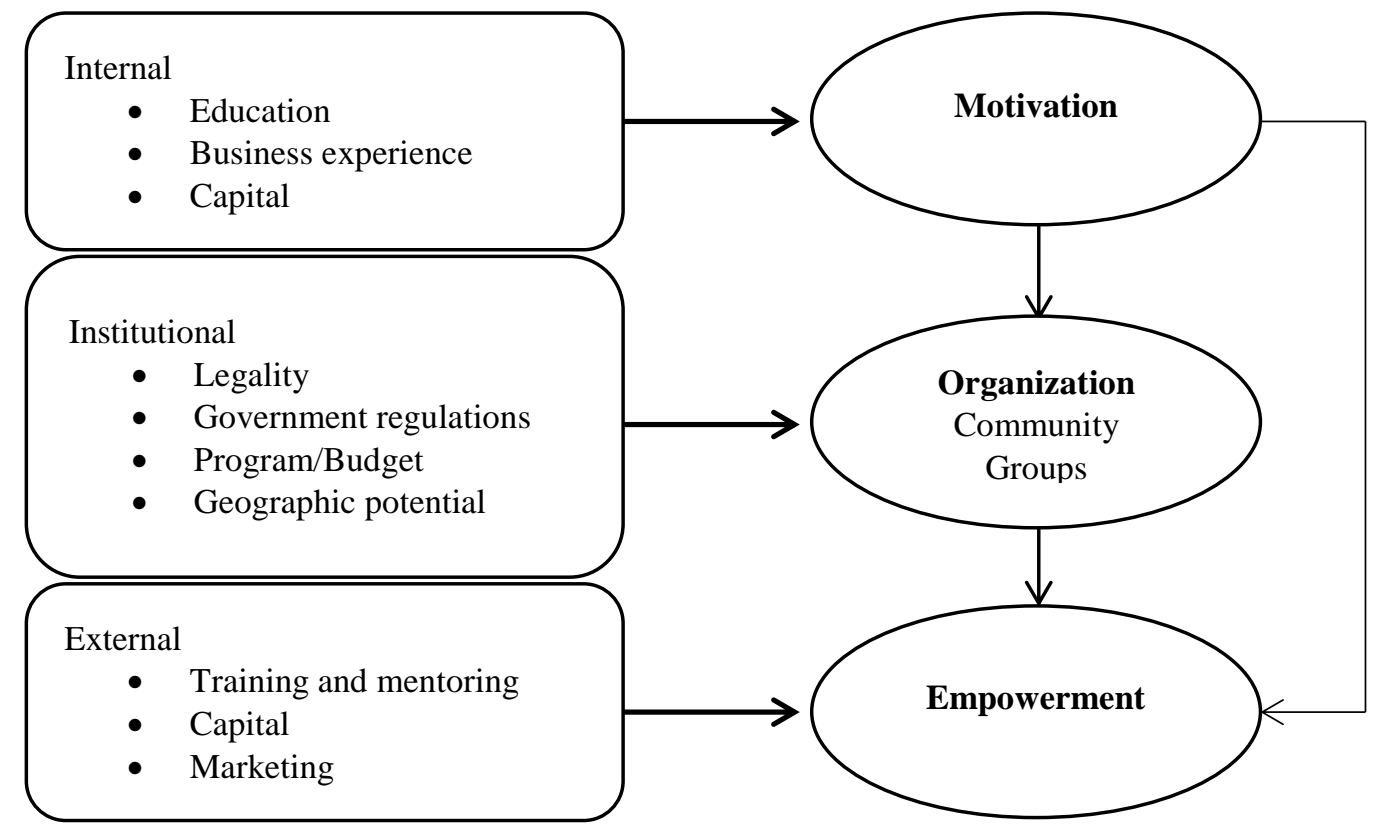

Figure 2. Community Empowerment Model

The model as shown above is then implemented onto the communities in accordance with the priorities. Consequently, the first step which needs to be taken by the government in empowering businesses and the community involved is by giving motivation that can stimulate the internal aspects owned by businesses and community. Motivation will be able to run smoothly when done in groups throughout the community groups or centers so that the legality of the business, government regulations, and programs and budgets would be set to be directly on target, as in accordance with the geographic potential of the area. Motivation and organization, if collaborated in training and mentoring, in accordance with the need of production quality improvement, the opening of capital and marketing network, would be able to enhance community empowerment thereby getting the respective parties ready to face the AEC.

In addition, the MSMEs empowerment is also necessary for preparing Wonogiri to be competitive in the AEC market. The MSMEs have an important role in terms of labor absorption and economic driving force. However, the MSMEs commonly experience obstacles such as limited working capital, low quality human resources, and low mastery of science and technology. Thus, inadequate planning, vision, and mission and the lack of raw materials for the production process can also hamper business prospects. The problem is further compounded when other problems such as marketing, capital, energy availability, infrastructure and information, and non-physical problems including high inflation, skill, and labor regulations exist.

It has to be emphasized that the development of a product, service, and human resource innovation, mastery of technology, and market expansion are all important for the purpose of empowering the MSMEs in facing globalization. The Bank of Indonesia, for example, has done its best in terms of capacity building through strengthening the SMEs by offering trainings. This observation is also highlighted by Setyobudi (2007) who notes that several efforts have also been included for the training for example Training for MSMEs companion agencies, both for the purpose to access banking and to finance the MSMEs companion accreditation and the Development of Integrated Information System for Small Business Development (SIPUK). 
Based on the in-depth interviews conducted with stakeholders in Wonogiri, as is contained in the MediumTerm Development Plan (RPJMD), the current community development plan is seen to be too general and in fact, it has not touched on the AEC issues. In particular, community and village empowerment in Wonogiri further encounters the following problems:

a. Appropriate technology suitable with the needs of community has not been utilized optimally.

b. The role and function of public institutions have not been conducted optimally.

c. Community participation in the development of rural areas have been declining.

d. Village government services to the community have not been optimal.

e. The role of women in the development is not optimal.

f. The ability of village finance in the development is limited.

g. Administrative management of village government is less orderly.

Descriptions to resolve the issues have not been done significantly by the Government of Wonogiri, but the government has devised empowerment program plans which aims to improve the productivity and competitiveness of Wonogiri. Nonetheless, these programs are still too general, as seen below:

a. Improve farmers' empowerment with indicators such as increasing famers' exchange rate so that farmers can improve their welfare. The structure that is based on the agrarian economy dictates that the government pays more attention to farmers.

b. Improve the MSMEs empowerment with indicators such as the availability of public infrastructure in the Creative Economy Cluster. The Wonogiri Cluster needs assistance so as to run as expected.

\section{Conclusions and Recommendations}

In the case of the Wonogiri regency, the ease to gain business access is required so as to be ready to face the AEC. This $t$ can be done by the government in collaboration with other stakeholders by providing training on financial reporting, facilitation on obtaining business legality and information.

The most influential aspect on community empowerment is Internal aspect which looks at how education is ranked highest, followed by capital owned and business experience. The institutional aspect which consists of business legality, government regulations, program and budget, and geographical conditions occupies second position. Meanwhile, the external aspect occupies the third position, in which the market factor is the most important factor, followed by training and mentoring, and capital.

Community empowerment model for the ASEAN Economic Community has not been specifically conducted in Wonogiri. Thus, in drawing up a strategic plan for the period of 2016-2020 as contained in RPJMD Wonogiri, the government can plan and develop and implement a more strategic empowerment program rather than one that is general.

\section{References}

ASEAN, (2008). ASEAN Economic Community Blue Print, The ASEAN Secretariat, Indonesia.

Deliarnov. (1997). Sejarah Pemikiran Ekonomi. Jakarta. Rajawali Pers.

Hariyadi, P. (2010). Penguatan Industri penghasil Nilai Tambah Berbasis Potensi Lokal Peranan Teknologi Pangan untuk Kemandirian Pangan. Jurnal Pangan. 19(4), 295-301.

Meilani, E. (2008). Analisis Dampak Perdagangan Bebas Indonesia-jepang dengan Pendekatan Global Trade Analysis Project (GTAP). Thesis. Tidak untuk dipublikasiakan. Depok. Universitas Indonesia.

Ricardo, D. (1817). Principles of political economy and taxation. London: J. Murray.

Riza, R. \& Roemidi. (2006). Pemberdayaan Masyarakat. Sumedang. Alqaprint Jatinangor.

Saharudin. (2009). Pemberdayaan Masyarakat Miskin Berbasis Kearifan Lokal, Jurnal Trandisiplin Sosiologi, Komunikasi dan Ekologi Manusia, 3(1), 17-44. 
Setyobudi, A. (2007). Peran Serta Bank Indonesia Dalam Pengembangan Usaha Mikro, Kecil dan Menengah (UMKM). Buletin Hukum Perbankan dan Kebanksentralan, 5(2).

Smeru. (2007). Kapasitas Kelembagaan Penanggulangan Kemiskinan di Daerah. Newsletter No. 21: Jan-Mar/2007 Smith, A. (1776). The wealth of nations. New York: The Modern Library.

Sulistiyani, A. T. (2004). Kemitraan dan Model-Model Pemberdayaan. Yogyakarta. Gaya Gava Media.

Subejo \& Iwamoto, N. (2003). Labor Institutions in Rural Java: A Case Study in Yogyakarta Province. Working Paper Series No. 03-H-01. Dept. of Agriculture and Resource Economics. Tokyo. The University of Tokyo.

Wardhani, A, \& Haryadi, M. (2004). Pemberdayaan Masyarakat Dalam Penanggulangan Kemiskinan. Jakarta. TKP3KPK, Menko Kesra.

Wittman, V. (2012). Gender and Empowerment in South Africa, Multicultural Education and Technology Journal, 6(4), 248-260. 